\title{
The Impacts of Social Enterprises on Labor Market Outcomes: Evidence from Vietnam
}

\author{
Nghia Thi Thu Nguyen, Cheng-Tao Tang and Chun Yee Wong *
}

Citation: Nguyen, N.T.T.; Tang, C.-T.; Wong, C.Y. The Impacts of Social Enterprises on Labor Market Outcomes: Evidence from Vietnam. Sustainability 2021, 13, 10864. https://doi.org/10.3390/ su131910864

Academic Editor: Carla Maria Marques Curado

Received: 27 August 2021

Accepted: 28 September 2021

Published: 30 September 2021

Publisher's Note: MDPI stays neutral with regard to jurisdictional claims in published maps and institutional affiliations.

Copyright: (c) 2021 by the authors. Licensee MDPI, Basel, Switzerland. This article is an open access article distributed under the terms and conditions of the Creative Commons Attribution (CC BY) license (https:/ / creativecommons.org/licenses/by/ $4.0 /)$.
Graduate School of International Relations, International University of Japan, Niigata 949-7277, Japan; nghiantt@iuj.ac.jp (N.T.T.N.); ct.tang@iuj.ac.jp (C.-T.T.)

* Correspondence: jcywong@iuj.ac.jp

\begin{abstract}
This study examines whether social enterprise development improves labor market outcomes of the entire economy. Using the data of social enterprise and labor force survey in Vietnam, we conduct a regression analysis to address this question. We focus on the rapid growth period of social enterprises in Vietnam during the early 2010s. Our results suggest that, as the number of social enterprises increases, average labor earnings increase, the probabilities of being unemployed and being self-employed decrease, and average working hours increase. Since our study evaluates the effect of social enterprise development on the outcomes for the overall labor market rather than the social enterprise sector alone, it provides justification for promoting such a policy from policymakers' point of view.
\end{abstract}

Keywords: social enterprises; labor market outcomes; sustainable development; gender

\section{Introduction}

Social enterprises-commonly understood as businesses that prioritize the achievement of social and environmental benefits over profit-making for their owners-have received increasing global attention from both social and economic standpoints. Policies to promote social enterprises (hereafter referred to as SEs) have become popular not only in the OECD countries, but also in many developing countries such as members of the Association of Southeast Asian Nations [1]. This growing attention is prompted by an urgent need to reconcile economic development with social and environmental sustainability, in which the modern economy has proved incapable of satisfying individuals with a range of preferences in an uncertain and resource-constrained environment [2]. While social enterprise promotion policies differ in their specifics and may be distributed across various industrial sectors within an economy, most of them include subsidies or tax incentives to encourage the utilization of non-market resources (e.g., financial donations and voluntary labor) and disadvantaged groups in the labor market, in the hope of reducing unemployment and ensuring a sustainable economy.

Despite growing interest, only a few quantitative studies have evaluated the effect of social enterprise development on macroeconomic outcomes. For example, Doh [3] explores the effect of social entrepreneurship on regional economic development (i.e., regional GDP) by focusing on government-driven social enterprises in South Korea. He confirmed the positive effects of social entrepreneurship, measured by the number of SEs, on economic development. In addition, using data from India, Di Lorenzo and Scarlata [4] demonstrate that SEs receiving venture philanthropy investment can lead to a decrease in levels of income inequality within municipalities. Lastly, using individual data from cities in Luxembourg, Sarracino and Fumarco [5] show that SEs can contribute to the well-being of individuals, where their social enterprise development is measured by the share of SEs in each city and the well-being is measured by a subjective index from survey.

However, among existing studies, macroeconomic consequences regarding labor market outcomes are missing. As the main target of SEs is to address disadvantaged 
workers within society, it is important to assess whether social enterprise development improves labor market outcomes. Moreover, since governments' policies in promoting SEs would affect all aspects of the economy, labor market outcomes should be evaluated in the context of an entire economy rather than the SE sector alone. For example, if the growth of SEs simply results in the redistribution of economic resources in favor of disadvantaged workers rather than an increase in efficiency of the entire economy, the overall labor outcomes would not be improved (or may even be reduced if more economic resources are directed to low-skilled workers at the expense of high-skilled workers), not to mention sustainable long-term economic growth.

This paper aims to fill the gap by analyzing the effect of social enterprise development on labor market outcomes of the entire economy. To address this issue, we draw on the literature on social enterprise development (see Section 2 for discussion) and develop a set of hypotheses. The first set of hypotheses asserts that the increase of SEs reduces the unemployment rate and increases the labor force participation of the economy. The second set of hypotheses asserts that, in a developing economy, the increase of SEs increases labor earnings. We test these hypotheses using a pooled cross-section of Vietnamese individual labor data and provincial-level social enterprise data from 2010 and 2017. Since, in practice, policy incentives regarding the degree of social enterprise development depend on Vietnamese provincial-level governments, we employ a linear regression model with both year-fixed and location-fixed effects, which is an extension of the basic differencein-differences methodology with multiple control and treatment groups over two time periods. The labor market outcomes covered in our empirical analysis include labor earnings, unemployment, labor force participation, working hours, and self-employment.

We demonstrate that, as the number of SEs increases, average labor earnings increase, the probabilities of being unemployed and being self-employed decrease, and average working hours increase. We also show that female individuals benefit marginally more than their male counterparts from the existence of SEs. This paper is, to the best of our knowledge, the first study to empirically examine the effect of social enterprise development on labor market outcomes of an entire economy rather than outcomes in the SE sector alone. In the political and economic debate, the accusation of social dumping is sometime made against SEs due to their low wage payment [6]. Our results thus provide a justification that, in the developing economy, it is beneficial to promote SEs from a macroeconomic point of view. This also provides policymakers with empirical evidence on implementing relevant policies to support the development of SEs.

The next section of the paper discusses theoretical considerations. Section 3 explains the institutional background of SE in Vietnam. This is followed by a description of the data and empirical strategy in Section 4. Section 5 presents the results from estimating the effect of SE on five labor market outcomes, along with a robustness and subsample analysis. Finally, Section 6 offers concluding remarks.

\section{Theoretical Considerations}

Social enterprises appear in various forms since their concrete expressions are deeply rooted in the social, economic, and political contexts from which these organizations emerge [7]. It follows that there is no agreed definition of social enterprise [8]. However, the institutional characteristics of SEs can be identified using three key dimensions-objectives, entrepreneurship, and governance [2]. First, SEs' objectives are to produce goods for public benefit and to meet social needs. Second, even in the absence of a motive that is focused purely on profit maximization, the social objectives can be sufficient to motivate entrepreneurial ventures and achieve the economic sustainability of those ventures. Third, inclusive and participatory governance is well utilized among SEs since they focus on the interests of all parties involved in the ventures rather than the narrow interests of investors. Participation by a broader range of actors, both within the organization and its community, also facilitates an SE's provision of public goods and satisfaction of social needs. Thanks to their distinctive features, SEs provide an alternative to public agencies 
and profit-maximizing firms by creating economic value in socially and environmentally sustainable ways.

The process of defining the key features of SEs has been advanced by groundbreaking legislation in the UK during 2004 and in Italy during 2006 [6]. The trend of promoting SEs with legal frameworks has also spread to the developing countries [9]. Note that, in the standard economic theorem of general equilibrium, the increased supply by SEs would simply reduce the supply provided by the public and for-profit sectors. If that is the case, there is no strong need to promote SE due to its crowding-out effect on the production of other sectors. However, the validity of such an argument relies on the fact that there is no market failure due to any setback of market structure or government policies (reasons for market failure include asymmetric or incomplete information, abuse of monopoly power, and difficulty in obtaining the market value of externality). When the market is inefficient, it is not surprising that several countries consider SEs as important players in the modern economic system.

Hence, a situation where SEs interact with other for-profit enterprises, which are mostly small and medium enterprises, should not be a zero-sum game. This is because the social objectives of SEs urge them to recoup productive capacity and utilize resources that would otherwise remain unused. Specifically, the intrinsic and pro-social motivation of the workers or employer within SEs help to increase their productivity even if highpower incentives are not applied. Additionally, since workers can be compensated by non-monetary motivation, lower wage payment allows SEs to enjoy a certain degree of competitive advantage, which means that SEs less often revert to costly monetary rewards and incentives and, as a result, are more efficient and sustainable. This directly contributes to the reduction of unemployment, at the margin, within the economy. Furthermore, by mitigating the underprovision of public goods and general-interest services, such as the provision of care for children and the elderly, SE supports the development of economic activities outside of its regime. Combining with their utilization of non-market resources, such as financial donations and voluntary work, SEs help to increase the overall stock of productive assets in the society and, thus, indirectly move up the production frontier of the economy. See [10] for a related discussion.

Consequently, the increase of SEs can reduce unemployment rates within the society because of the direct inclusion of otherwise unemployed workers within the SE sector and the indirect push in labor demand toward a more efficient economy beyond the SE sector. Labor force participation rate, as one of the important labor market outcomes, would also increase due to augmented opportunities from all sectors. The labor market earnings (i.e., income from waged employment, salaried employment, and self-employment) in the SE sector, on average, may not change because the lower wage payment for the existing labor force is offset by the increased earnings from self-employed individuals and workers that would otherwise be excluded from the labor force. However, if the labor market of an economy is relatively fragmented (urban versus rural or formal versus informal sectors), which is the case especially in the developing countries, the increased efficiency of the economy would result in higher labor earning overall [11]. Increased efficiency may not result in additional employment in some parts of labor markets, such as non-SE sectors among which the skill requirement is higher and entry is restricted. Instead, it can only shift the labor demand outward and, thus, increase wages for those already employed. Therefore, we would expect an overall positive impact of SEs on labor earnings, especially in the developing economies.

\section{Legal Recognition and Promotion of Social Enterprises in Vietnam}

The Center for Social Initiatives Promotion (CSIP) has contributed to the early development of SEs and promoted the SE concept in the policy domain in Vietnam since 2008. As stipulated in Decree No. 69 of 2008, the provincial governments, including provinces and centrally run cities in Vietnam, assume the prime responsibility of enterprise supporting policies (e.g., funding and preferential tax treatment) for socialization in education and 
training, medicine, culture, and environment. However, it was not until the period of the early 2010s that SE, under its broad definition, proliferated in Vietnam [12,13].

Since 2010, Vietnam has ascended to the group of "lower middle-income" countries. Many large development agencies thus started to put an end to their development programs and shifted resources to poorer countries. Hence, external aid has become competitive and scarce for local non-governmental organizations (NGOs). This circumstance also pushed many local NGOs to look for various income sources. Against this background, CSIP and its partners, such as the British Council and Spark Center, entered the scene and actively introduced SE as an alternative organization model that fits the new social and economic context. They played the role of professional intermediaries that incubated social enterprise initiatives and strengthened existing organizations' operations through training, networking, and research services. Many of the SEs that emerged during the period of the early 2010s can be classified into three groups, depending on the context of their creation: (1) non-profit social enterprises usually transformed from local NGOs by setting up business branches to enhance the sustainability of the organizations, (2) nonprofit social enterprises that are mainly operated under corporate form and established by social entrepreneurs or incubated by professional intermediaries, and (3) for-profit social enterprises with social orientation, which are usually in the form of cooperatives. Notice that the classification of SEs in Vietnam varies depending on either the creation process or the form of the organization. See [12-14] for detailed discussions on different types of SEs. In 2013, a supporting policy particularly for cooperatives was initiated (i.e., Decree 193/2013/ND-CP), which offers subsidies for formal and technical training, trade and market expansion, and the application of new technologies.

Efforts to promote the growth of SE led to its legal recognition for the first time in Vietnam. In 2014, the amended Law on Enterprise (LOE) introduced a new article that formally defined social enterprise and its obligations. In addition, Decree No. 96 in 2015 provided policy guides to support social enterprises and clearly assigned the responsibilities of incentive provision and business supervision to provincial governments. According to LOE, an "official social enterprise" is defined as a registered enterprise under this law that meets core criteria including: (1) its objectives are to solve social and environmental issues in the interest of the community, and (2) it uses at least $51 \%$ of its annual profit to reinvest for the purpose of social and environmental goals as registered. However, the new SE supporting policy introduced in Decree No. 96 is still very modest. For example, SEs that are registered under LOE are allowed to mobilize, as well as receive grants and donations, but they do not benefit from value-added tax exemption and corporate tax reduction. Additionally, the mechanism through which social enterprises receive government subsidies is not clear and mainly depends on local governments. Hence, many emerging and existing Vietnamese SEs, under their broad definition as in [12] or [13], still choose not to register as official SEs (i.e., registered under LOE) and operate in other forms such as cooperatives, NGOs, or for-profit enterprises. Based on British Council figures [15], a total of 54 enterprises have registered as official SEs since LOE became effective.

According to the databases of CSIP and iMap Vietnam, compiled by the Center for Social Innovation and Entrepreneurship (CSIE), the number of SEs in Vietnam was 217 in 2010 and around 85\% were located in either Hanoi or Ho Chi Minh City. In 2017, the number of SEs was 606, which almost tripled the number in 2010. Many new SEs have also been established in the provinces outside of Hanoi and Ho Chi Minh City, indicating that the emphasis of social enterprise development has become nationwide.

\section{Data and Methodology}

\subsection{Data}

To evaluate the impact of social enterprise during its period of rapid growth in Vietnam during the early 2010s, we utilized data from two sources in the years of 2010 and 2017, respectively. The first was a combined dataset of social enterprise in Vietnam from the existing databases of CSIP and iMap Vietnam (compiled by CSIE), respectively. 
The collected enterprises or organizations meet the broad definition of SE in Vietnam as discussed in Section 3. They include official SEs (registered under LOE) and enterprises with social missions or having social impact in the country. After the merging of these datasets, we obtained a list of unique SEs by removing duplicated firms. The resulting dataset provided information on variables of interest including the number of SEs and their industrial sector categories (agriculture, service, and others) in 63 provinces or centrally run cities in 2010 and 2017.

The second data source was the Vietnam Labor Force Survey (VLFS). We included two waves of the VLFS from 2010 and 2017 for this analysis. VLFS is a nationwide representative survey, which is carried out by the General Statistics Office of Vietnam. The survey covers individuals aged 15 and above to collect information about their sociodemographic characteristics and activities in relation to the labor market. In the VLFS 2010 and 2017, the numbers of working-age individuals (i.e., aged 15 to 64) were 627,114 and 517,656, respectively. Both surveys provided individual-level information that is important in characterizing the labor market. These two waves of VLFSs were first appended by year and then merged with social enterprises' data (by area of provincial government) to form a consolidated dataset for analysis. After excluding observations with missing data, the final sample consisted of 813,864 individuals distributed across 63 provincial governments in Vietnam in 2010 and 2017.

The dependent variables for this analysis are five different measures of the labor market outcomes of individuals: labor earnings, status of being unemployed, labor force participation, working hours, and status of being self-employed. When measuring the impact of social enterprise development, we used the number of SEs per province or centrally run city as the proxy, in which a larger number of SEs represents a higher degree of their development. In order to investigate whether different industrial sectors of SEs have heterogenous effects on labor market outcomes, we further constructed the percentages of SEs for different industrial sectors in each province and centrally run city as independent variables. In particular, we focused on shares of SE in the agricultural and service sectors and treated these shares in other sectors (mostly from the manufacturing sector) as our reference group in the analysis. The remaining control variables in our regression model are exogenous sociodemographic characteristics of individuals, which include gender, marital status, and age. The detailed definitions of the dependent and independent variables are provided in Table 1.

Table 1. Definition of the variables.

\begin{tabular}{|c|c|}
\hline Variables & Description \\
\hline \multicolumn{2}{|r|}{ Dependent variables } \\
\hline Earnings & $\begin{array}{l}\text { Income from a wage, salary, or self-employment per month in thousands of Vietnamese dong at } \\
\text { constant price level in } 2010 .\end{array}$ \\
\hline Unemployed & $\begin{array}{l}\text { Binary variable; it equals } 1 \text { if an individual is currently unemployed (i.e., he/she does not have a job } \\
\text { and is searching for employment at that time), and it equals } 0 \text { if an individual is currently employed. }\end{array}$ \\
\hline LFP & $\begin{array}{l}\text { Binary variable; it equals } 1 \text { if an individual participates in the labor force (i.e., he/she either has a job } \\
\text { or is searching for employment at that time), and it equals } 0 \text { otherwise. }\end{array}$ \\
\hline Work hours & $\begin{array}{l}\text { Total working hours per week of an individual who is currently employed, including main job and } \\
\text { extra jobs. }\end{array}$ \\
\hline Self-employed & $\begin{array}{l}\text { Binary variable; it equals } 1 \text { if an individual works in an individual-owned business (sole } \\
\text { proprietorship) in production and trade, and it equals } 0 \text { if an individual works under other } \\
\text { ownership types. }\end{array}$ \\
\hline \multicolumn{2}{|r|}{ Independent variables } \\
\hline SE & Number of social enterprises. \\
\hline AgriPCT & Percentage of social enterprises in agricultural sector. \\
\hline ServPCT & Percentage of social enterprises in service sector. \\
\hline GRDP & Gross regional domestic product in billions of Vietnamese dong at current price level. \\
\hline Female & Binary variable; it equals 1 if an individual is female and 0 otherwise. \\
\hline Married & Binary variable; it equals 1 if an individual is married and 0 otherwise. \\
\hline Age & Age of an individual. \\
\hline Agesq & Age square of an individual. \\
\hline
\end{tabular}




\subsection{Empirical Method}

This analysis utilizes the pooled cross section to examine the average treatment effects of SEs on labor market outcomes. We have deployed a linear model with year-fixed and location-fixed effects, which is an extension of the basic difference-in-differences methodology with multiple control and treatment groups over two time periods. The model provides a framework for estimating the treatment effects by allowing different interventions that happened at different times with some groups of entities serving as control groups (i.e., never treated) and others being treated in different time periods [16]. The main regression model to be estimated is as follows:

$$
y_{i g t}=\alpha_{0}+\beta_{1} S E_{g t}+\beta_{2} A_{g r i P C T}{ }_{g t}+\beta_{3} \operatorname{ServPCT}_{g t}+\gamma G R D P_{g t}+Z_{i g t} \delta+\text { provincial }_{g} \pi+\tau Y 2017_{t}+u_{i g t}
$$

As discussed in the previous subsection, $y_{\text {igt }}$ are the variables of individual $i$ 's labor market outcomes including earnings, being unemployed, labor force participation, working hours, and being self-employed. For the variables of being unemployed, labor force participation, and being self-employed, this model is interpreted as the linear probability model since the dependent variable is binary and, hence, the response probability is linear in the coefficients. The subscripts $g$ and $t$ represent the area of provincial government and year, respectively. The variables of interest in this analysis are $S E, A g r i P C T$, and $S$, and the coefficients $\beta_{1}, \beta_{2}$, and $\beta_{3}$ represent the average treatment effects of the number of SEs and the percentages of SEs in agricultural and service sectors on labor markets outcomes, respectively. The variable of $G R D P_{g t}$ measures the economic performance in the area $g$ in year $t$. The notation $Z_{i g t}$ is a row vector of an individual's sociodemographic characteristics, provincial $_{g}$ is a row vector of location-fixed effects, $Y 2017_{t}$ is a dummy variable indicating the year 2017 , and $u_{\text {igt }}$ is the idiosyncratic error.

Equation (1) allows us to compare the average labor market outcomes of different groups of individuals who lived in different provincial areas and experienced different increments of SEs in their localities between 2010 and 2017. However, there is one potential endogeneity problem concerning the number of SEs per provincial area. In particular, social enterprises may self-select to establish their business in a particular province or centrally run city because of the demographic or institutional factors of each local area. Including the provincial area, fixed effects in the model can partially resolve this problem if the provincial area-specific factors that may influence SEs' location choice are time invariant. Moreover, we included the regional GDP of each provincial area in the model. This is because the selection of the establishment of SEs may be based on provincial-level economic conditions that are time variant, and the economic performance of each local area may also affect the profitability and, hence, the sustainability of SEs. We included the regional GDP variable in order to capture the effect of (time-variant) economic performance in each province and centrally run city in a particular year.

Another potential threat to this analysis is the measurement error of the numbers of SEs per provincial area. As discussed in the previous subsection, the number of unique SEs in a particular province or centrally run city was consolidated from CSIP and CSIE (by removing duplicated SEs). Since the data of SEs were collected from different sources and via different channels, this variable may suffer from measurement errors. To deal with this potential problem, we adopted the instrumental variable (IV) method as a robustness check. We used the total number of firms registered in each provincial area in 2009 and 2016 (the time immediately prior to the year of our study) to serve as the IV for the number of SEs in each provincial area in 2010 and 2017, respectively. This variable can be justified as a valid IV because, first, the total number of firms in each provincial area at the beginning of the year should be highly correlated with the number of SEs in that provincial area in year $t$ and, hence, it is likely to fulfill the relevance requirement of being a valid IV. Second, the total number of firms in each provincial area in year $t-1$ is expected to be exogeneous as it had happened in the past. Therefore, it is uncorrelated with the error term $u_{i g t}$ and the 
assumption of exclusion restriction is plausible. The IV estimation was performed using two-stage least squares (2SLS) and the results are presented in Section 5.2.

\subsection{Summary Statistics}

Table 2 provides the summary statistics for the variables used in the estimation. The sample consisted of 813,864 individuals in total. There were 367,127 and 446,737 in 2010 and 2017, respectively. In general, the labor market outcomes in Vietnam had improved between 2010 and 2017. On average, real earning increased by 18.6\%, from VND 2480.15 thousand to VND 2940.53 thousand, and working hours decreased by $5.45 \mathrm{~h}$ per week. Although the percentage of labor force participation had remained almost the same, which was around $80 \%$ in both years, the percentage of individuals who were unemployed in 2017 had declined by two percentage points since 2010.

Table 2. Summary statistics by year.

\begin{tabular}{|c|c|c|c|c|c|c|}
\hline Variable & Obs & $\begin{array}{c}2010 \\
\text { Mean }\end{array}$ & Std. Dev. & Obs & $\begin{array}{c}2017 \\
\text { Mean }\end{array}$ & Std. Dev. \\
\hline Earning & 110,642 & 2480.15 & 2015.98 & 363,822 & 2940.53 & 3287.00 \\
\hline Unemployed & 297,857 & 0.03 & 0.17 & 367,843 & 0.01 & 0.10 \\
\hline LFP & 367,127 & 0.81 & 0.39 & 446,737 & 0.82 & 0.38 \\
\hline Work hours & 289,014 & 45.58 & 10.91 & 363,581 & 40.13 & 13.90 \\
\hline Self-employed & 289,014 & 0.27 & 0.44 & 363,822 & 0.04 & 0.20 \\
\hline $\mathrm{SE}$ & 367,127 & 6.75 & 16.96 & 446,737 & 29.24 & 70.09 \\
\hline AgriPCT & 367,127 & 38.52 & 41.50 & 446,737 & 40.86 & 36.07 \\
\hline ServPCT & 367,127 & 37.22 & 39.75 & 446,737 & 43.95 & 33.07 \\
\hline GRDP & 367,127 & $55,936.27$ & $96,471.73$ & 446,737 & $98,522.98$ & $190,137.50$ \\
\hline Female & 367,127 & 0.51 & 0.50 & 446,737 & 0.51 & 0.50 \\
\hline Married & 366,638 & 0.68 & 0.47 & 446,731 & 0.72 & 0.45 \\
\hline Age & 367,127 & 35.72 & 13.31 & 446,737 & 38.52 & 13.64 \\
\hline Agesq & 367,127 & 1452.93 & 1003.80 & 446,737 & 1669.99 & 1072.12 \\
\hline TotalFirm & 367,127 & 6628.86 & $16,191.03$ & 446,737 & $25,708.89$ & $54,340.76$ \\
\hline
\end{tabular}

Notes: (1) Earnings are in thousands of Vietnamese dong (VND), adjusted by 2010 constant price. In 2010, one US dollar was equivalent to around VND 19,000. (2) GRDP contains the GDP of a province or centrally-run city at current prices in billion dong. (3) The instrumental variable of TotalFirm contains the total number of businesses operating in a province or centrally-run city.

Between 2010 and 2017, the average number of SEs per provincial area had increased significantly from 6.75 to 29.24 . The majority of SEs were in agricultural and service sectors which, in combination, comprised $75.74 \%$ and $84.81 \%$ of all the SEs in 2010 and 2017, respectively. The remaining SEs belonged to the manufacturing sector. The average GDP per provincial area increased considerably from VND 55,936 billion to VND 98,523 billion between 2010 and 2017. The total number of firms per provincial area also significantly increased between this period from 6629 to 25,709 per provincial area.

\section{Empirical Results}

\subsection{Regression Results}

Tables 3 and 4 present the regression results for five outcome variables of earnings, being unemployed, labor force participation, working hours, and being self-employed. Columns (\#a) show the results for the simple model, while the columns (\#b) show the results for the full model, which includes the individual characteristics of gender, marital status, and age.

Table 3 indicates that a higher number of SEs improves individuals' earnings and reduces unemployment, although it seems to have no effect on labor force participation. The results from the full models show that one additional SE per provincial area increased the monthly earnings of an individual by VND 5430 on average, at a significance level of $1 \%$. For the people in the labor force, one additional SE per provincial area reduced the probability of being unemployed by $0.008 \%$ on average, which is statistically significant at a level of $1 \%$. Although the partial effect of SE on being unemployed was small in 
magnitude, this effect was still considerably influential since the labor force of Vietnam is relatively large compared with those of other countries in Asia-the size of the labor force in Vietnam was 56.5 million in 2020, which was the third-largest in Asia [17].

Table 3. Regression results for earnings, being unemployed, and labor force participation.

\begin{tabular}{|c|c|c|c|c|c|c|}
\hline & (1a) & (1b) & (2a) & $(2 b)$ & (3a) & $(3 b)$ \\
\hline Dependent Variable & Earnings & Earnings & Unemployed & Unemployed & LFP & LFP \\
\hline SE & $\begin{array}{c}6.09 * * * \\
(1.58)\end{array}$ & $\begin{array}{c}5.43^{* * *} \\
(1.41)\end{array}$ & $\begin{array}{c}-0.00008^{* * *} \\
(0.00001)\end{array}$ & $\begin{array}{c}-0.00008^{* * *} \\
(0.00001)\end{array}$ & $\begin{array}{c}0.00 \\
(0.00)\end{array}$ & $\begin{array}{c}0.00 \\
(0.00)\end{array}$ \\
\hline AgriPCT & $\begin{array}{l}3.66 \\
(7.88)\end{array}$ & $\begin{array}{c}3.58 \\
(7.08)\end{array}$ & $\begin{array}{c}0.00 \\
(0.00)\end{array}$ & $\begin{array}{c}0.00 \\
(0.00)\end{array}$ & $\begin{array}{c}0.00 \\
(0.00)\end{array}$ & $\begin{array}{c}0.00 \\
(0.00)\end{array}$ \\
\hline ServPCT & $\begin{array}{l}-0.43 \\
(6.53)\end{array}$ & $\begin{array}{l}-0.60 \\
(5.84)\end{array}$ & $\begin{array}{c}0.00 \\
(0.00)\end{array}$ & $\begin{array}{c}0.00 \\
(0.00)\end{array}$ & $\begin{array}{c}0.00 \\
(0.00)\end{array}$ & $\begin{array}{c}0.00 \\
(0.00)\end{array}$ \\
\hline Y2017 & $\begin{array}{c}337.14^{* * *} \\
(124.98)\end{array}$ & $\begin{array}{c}361.38^{* * *} \\
(113.29)\end{array}$ & $\begin{array}{c}-0.02 * * * \\
(0.00)\end{array}$ & $\begin{array}{c}-0.01 * * * \\
(0.00)\end{array}$ & $\begin{array}{c}0.02 * * * \\
(0.00)\end{array}$ & $\begin{array}{l}0.01 * \\
(0.00)\end{array}$ \\
\hline GRDP & $\begin{array}{c}0.00^{* * *} \\
(0.00)\end{array}$ & $\begin{array}{c}0.00^{* * *} \\
(0.00)\end{array}$ & $\begin{array}{c}-0.00^{* * *} \\
(0.00)\end{array}$ & $\begin{array}{c}-0.00^{* * *} \\
(0.00)\end{array}$ & $\begin{array}{c}0.00 \\
(0.00)\end{array}$ & $\begin{array}{c}-0.00 * * \\
(0.00)\end{array}$ \\
\hline Female & & $\begin{array}{c}-948.16^{* * *} \\
(39.36)\end{array}$ & & $\begin{array}{c}0.00 * * \\
(0.00)\end{array}$ & & $\begin{array}{c}-0.07^{* * * *} \\
(0.01)\end{array}$ \\
\hline Married & & $\begin{array}{c}132.50^{* * *} \\
(20.06)\end{array}$ & & $\begin{array}{c}-0.02^{* * *} \\
(0.00)\end{array}$ & & $\begin{array}{c}0.08^{* * *} \\
(0.01)\end{array}$ \\
\hline Age & & $\begin{array}{c}250.71 * * * \\
(12.17)\end{array}$ & & $\begin{array}{c}-0.01 * * * \\
(0.00)\end{array}$ & & $\begin{array}{c}0.07 * * * \\
(0.00)\end{array}$ \\
\hline Agesq & & $\begin{array}{c}-3.00 * * * \\
(0.16)\end{array}$ & & $\begin{array}{c}0.00^{* * *} \\
(0.00)\end{array}$ & & $\begin{array}{c}-0.00^{* * *} \\
(0.00)\end{array}$ \\
\hline Constant & $\begin{array}{c}2184.38 * * * \\
(617.88)\end{array}$ & $\begin{array}{c}-2121.04^{* * *} \\
(574.46)\end{array}$ & $\begin{array}{c}0.05 * * * \\
(0.01)\end{array}$ & $\begin{array}{c}0.17^{* * *} \\
(0.02)\end{array}$ & $\begin{array}{c}0.74 * * * \\
(0.02)\end{array}$ & $\begin{array}{c}-0.54^{* * *} \\
(0.05)\end{array}$ \\
\hline Province FE & Yes & Yes & Yes & Yes & Yes & Yes \\
\hline $\mathrm{N}$ & 474,464 & 474,297 & 665,700 & 665,350 & 813,864 & 813,369 \\
\hline R-sq & 0.05 & 0.101 & 0.007 & 0.026 & 0.016 & 0.261 \\
\hline
\end{tabular}

Notes: Standard errors, clustering within each province or centrally-run city, are in parentheses. ${ }^{* * *},{ }^{* *},{ }^{*}$ denote significance at $1 \%, 5 \%$, and $10 \%$, respectively.

Table 4. Regression results for working hours and being self-employed.

\begin{tabular}{|c|c|c|c|c|}
\hline & (4a) & $(4 b)$ & (5a) & (5b) \\
\hline Dependent Variable & Working Hours & Working Hours & Self-Employed & Self-Employed \\
\hline \multirow[t]{2}{*}{ SE } & $0.02 * * *$ & $0.02 * * *$ & $-0.0006^{* * *}$ & $-0.0007^{* * *}$ \\
\hline & $(0.01)$ & $(0.01)$ & $(0.0001)$ & $(0.0001)$ \\
\hline \multirow{2}{*}{ AgriPCT } & -0.02 & -0.02 & 0.00 & 0.00 \\
\hline & $(0.04)$ & $(0.04)$ & $(0.00)$ & $(0.00)$ \\
\hline \multirow[t]{2}{*}{ ServPCT } & -0.02 & -0.02 & 0.00 & 0.00 \\
\hline & $(0.02)$ & $(0.02)$ & $(0.00)$ & $(0.00)$ \\
\hline \multirow[t]{2}{*}{ Y2017 } & $-6.14^{* * *}$ & $-5.82^{* * *}$ & $-0.22^{* * *}$ & $-0.22^{* * *}$ \\
\hline & $(0.63)$ & $(0.62)$ & $(0.01)$ & $(0.01)$ \\
\hline \multirow[t]{2}{*}{ GRDP } & $0.00 * *$ & $0.00^{* *}$ & $-0.00 * *$ & $-0.00^{* *}$ \\
\hline & $(0.00)$ & $(0.00)$ & $(0.00)$ & $(0.00)$ \\
\hline \multirow[t]{2}{*}{ Female } & & $-2.10^{* * *}$ & & $-0.02 * * *$ \\
\hline & & $(0.15)$ & & $(0.01)$ \\
\hline \multirow[t]{2}{*}{ Married } & & $-0.70^{* * *}$ & & $-0.02 * * *$ \\
\hline & & $(0.12)$ & & $(0.00)$ \\
\hline \multirow[t]{2}{*}{ Age } & & $0.72 * * *$ & & $0.01 * * *$ \\
\hline & & $(0.04)$ & & $(0.00)$ \\
\hline \multirow[t]{2}{*}{ Agesq } & & $-0.01 * * *$ & & $-0.00 * * *$ \\
\hline & & $(0.00)$ & & $(0.00)$ \\
\hline \multirow[t]{2}{*}{ Constant } & $44.99 * * *$ & $35.53^{* * *}$ & $0.40^{* * *}$ & $0.29^{* * *}$ \\
\hline & $(2.44)$ & $(2.60)$ & $(0.06)$ & $(0.06)$ \\
\hline Province FE & Yes & Yes & Yes & Yes \\
\hline $\mathrm{N}$ & 652,595 & 652,261 & 652,836 & 652,502 \\
\hline R-sq & 0.078 & 0.105 & 0.125 & 0.128 \\
\hline
\end{tabular}

Notes: Standard errors, clustering within each province or centrally-run city, are in parentheses. ${ }^{* * *},{ }^{* *}, *$ denote significance at $1 \%, 5 \%$, and $10 \%$, respectively. 
Besides the main labor market outcomes, SEs also had significant effects on working hours and self-employed status, as shown in Table 4. On average, an additional SE per provincial area increased the weekly working time by $0.02 \mathrm{~h}$. Moreover, SEs had a significant negative effect on being self-employed. This is also considered as an improvement of the labor market outcomes, since self-employed workers are more often found in low productivity sectors and earn a relatively lower wage [18]. On the other hand, the regression coefficient values for the percentages of SE in agriculture and service sectors indicate no statistically significant effect.

For the control variables, their effects on labor earning were generally consistent with estimation results based on the standard Mincer equation [19] in previous studies such as [20]. That is, age had a positive effect on earnings and this effect followed a concave schedule. On average, females earned less than males and marriage exhibited a positive premium for labor earnings.

\subsection{Robustness Check-IV Estimation}

Table 5 presents the estimation results, using 2SLS, of the full models for the five outcome variables by employing the total number of firms in each province or centrally run city in $t-1$ as IV. We have argued, in Section 4.3 , that this IV is likely to satisfy relevance and exclusion conditions. We further confirmed this in our results in Table 5, given that the estimate of the first-stage regression showed that our IV is relevant to the variable of SE, significant at $1 \%$, for all of the outcome variables.

Table 5. Results from IV estimations.

\begin{tabular}{|c|c|c|c|c|c|}
\hline & (1) & (2) & (3) & (4) & (5) \\
\hline Dependent Variable & Earnings & Unemployed & LFP & Working Hours & Self-Employed \\
\hline SE & $\begin{array}{l}6.45^{* * *} \\
(2.03)\end{array}$ & $\begin{array}{c}-0.00006^{* *} \\
(0.00003)\end{array}$ & $\begin{array}{c}0.00 \\
(0.00)\end{array}$ & $\begin{array}{l}0.02 * * \\
(0.01)\end{array}$ & $\begin{array}{c}-0.001 \text { ** } \\
(0.000)\end{array}$ \\
\hline AgriPCT & $\begin{array}{c}3.62 \\
(6.97)\end{array}$ & $\begin{array}{c}0.00 \\
(0.00)\end{array}$ & $\begin{array}{c}0.00 \\
(0.00)\end{array}$ & $\begin{array}{l}-0.02 \\
(0.03)\end{array}$ & $\begin{array}{c}0.00 \\
(0.00)\end{array}$ \\
\hline ServPCT & $\begin{array}{l}-0.51 \\
(5.76)\end{array}$ & $\begin{array}{c}0.00 \\
(0.00)\end{array}$ & $\begin{array}{c}0.00 \\
(0.00)\end{array}$ & $\begin{array}{l}-0.02 \\
(0.02)\end{array}$ & $\begin{array}{c}0.00 \\
(0.00)\end{array}$ \\
\hline Y2017 & $\begin{array}{c}340.03^{* * * *} \\
(115.11)\end{array}$ & $\begin{array}{c}-0.01^{* * *} \\
(0.00)\end{array}$ & $\begin{array}{l}0.01 * * \\
(0.00)\end{array}$ & $\begin{array}{c}-5.77^{* * *} \\
(0.68)\end{array}$ & $\begin{array}{c}-0.22^{* * *} \\
(0.01)\end{array}$ \\
\hline GRDP & $\begin{array}{c}0.00 * * * \\
(0.00)\end{array}$ & $\begin{array}{c}-0.00 * * \\
(0.00)\end{array}$ & $\begin{array}{c}-0.00 \text { ** } \\
(0.00)\end{array}$ & $\begin{array}{l}0.00^{* *} \\
(0.00)\end{array}$ & $\begin{array}{c}0.00 \\
(0.00)\end{array}$ \\
\hline Female & $\begin{array}{c}-947.77^{* * *} \\
(38.97)\end{array}$ & $\begin{array}{l}0.00 * * \\
(0.00)\end{array}$ & $\begin{array}{c}-0.07 * * * \\
(0.01)\end{array}$ & $\begin{array}{l}-2.10^{* * *} \\
(0.15)\end{array}$ & $\begin{array}{c}-0.02^{* * *} \\
(0.01)\end{array}$ \\
\hline Married & $\begin{array}{c}132.71^{* * *} \\
(19.86)\end{array}$ & $\begin{array}{c}-0.02 * * * \\
(0.00)\end{array}$ & $\begin{array}{c}0.08^{* * *} \\
(0.01)\end{array}$ & $\begin{array}{c}-0.70^{* * *} \\
(0.12)\end{array}$ & $\begin{array}{l}-0.02^{* * *} \\
(0.00)\end{array}$ \\
\hline Age & $\begin{array}{c}250.55^{* * * *} \\
(12.03)\end{array}$ & $\begin{array}{c}-0.01^{* * *} \\
(0.00)\end{array}$ & $\begin{array}{c}0.07^{* * *} \\
(0.00)\end{array}$ & $\begin{array}{c}0.72 * * * \\
(0.04)\end{array}$ & $\begin{array}{c}0.01^{* * *} \\
(0.00)\end{array}$ \\
\hline Agesq & $\begin{array}{c}-2.99 * * * \\
(0.16)\end{array}$ & $\begin{array}{l}0.00 * * * \\
(0.00)\end{array}$ & $\begin{array}{c}-0.00^{* * * *} \\
(0.00)\end{array}$ & $\begin{array}{c}-0.01^{* * *} \\
(0.00)\end{array}$ & $\begin{array}{c}-0.00 * * * \\
(0.00)\end{array}$ \\
\hline Constant & $\begin{array}{c}-2350.60 * * * \\
(651.01)\end{array}$ & $\begin{array}{l}0.17^{* * *} \\
(0.02)\end{array}$ & $\begin{array}{c}-0.53^{* * *} \\
(0.05)\end{array}$ & $\begin{array}{c}36.13^{* * *} \\
(3.01)\end{array}$ & $\begin{array}{c}0.37^{* * * *} \\
(0.11)\end{array}$ \\
\hline Province FE & Yes & Yes & Yes & Yes & Yes \\
\hline $\mathrm{N}$ & 474,297 & 665,350 & 813,369 & 652,261 & 652,502 \\
\hline R-sq & 0.101 & 0.026 & 0.261 & 0.105 & 0.128 \\
\hline \multicolumn{6}{|c|}{ Estimate from the first-stage estimation } \\
\hline TotalFirm & $\begin{array}{c}0.001 * * * \\
(0.000)\end{array}$ & $\begin{array}{l}0.001 * * * \\
(0.000)\end{array}$ & $\begin{array}{c}0.001^{* * *} \\
(0.000)\end{array}$ & $\begin{array}{c}0.001 * * * \\
(0.000)\end{array}$ & $\begin{array}{c}0.001^{* * * *} \\
(0.000)\end{array}$ \\
\hline \multicolumn{6}{|c|}{ Test for endogeneity } \\
\hline $\begin{array}{c}\text { F-statistics } \\
p \text {-value }\end{array}$ & $\begin{array}{l}3.400 \\
0.071\end{array}$ & $\begin{array}{l}10.173 \\
0.002\end{array}$ & $\begin{array}{l}1.531 \\
0.221\end{array}$ & $\begin{array}{l}0.505 \\
0.480\end{array}$ & $\begin{array}{c}39.168 \\
0.000\end{array}$ \\
\hline
\end{tabular}

Notes: Standard errors, clustering within each province or centrally-run city, are in parentheses. ${ }^{* * *}, * *, *$ denote significance at $1 \%, 5 \%$ and $10 \%$, respectively. 
Moreover, when using [21] robust score for the test of endogeneity, the F-statistics result showed that the presumed endogenous variable, the number of SEs, may suffer from an endogeneity problem for the dependent variables of earnings, being unemployed, and being self-employed, where their F-statistics are 3.40, 10.17, and 39.17, respectively. However, there is little cause for concern about the endogeneity problem for the dependent variables of labor force participation and working hours based on the test results.

Note that, for the dependent variables of earnings, being unemployed, and being self-employed, their regression results from IV estimation are close to what we obtained from the linear models in Table 3, in terms of both magnitudes and signs. This means that, even though the linear models may suffer from the measurement error of the variable of SE for some dependent variables (i.e., earnings, being unemployed, and being self-employed), the estimated partial effects of SE on those outcome variables are still robust among the two different analysis strategies (i.e., both with and without IV). We therefore interpret results from the previous subsection, Tables 3 and 4, as our main results.

\subsection{Subsample Analysis by Gender}

The gender pay gap has been acknowledged and investigated for a long time in the economic literature [22-24]. Therefore, we have performed a subsample analysis that estimates the labor market effects of SE on males and females, respectively. Tables 6 and 7 present the results from estimating the full models for males and females.

Table 6. Regression results for earnings, being unemployed, and labor force participation by gender.

\begin{tabular}{|c|c|c|c|c|c|c|}
\hline & (1a) & (1b) & (2a) & (2b) & (3a) & $(3 b)$ \\
\hline \multirow[t]{2}{*}{ Dependent Variable } & \multicolumn{2}{|c|}{ Earnings } & \multicolumn{2}{|c|}{ Unemployed } & \multicolumn{2}{|c|}{ LFP } \\
\hline & Male & Female & Male & Female & Male & Female \\
\hline \multirow[t]{2}{*}{ SE } & $5.59^{* * *}$ & $5.65^{* * *}$ & $-0.00006^{* * *}$ & $-0.0001^{* * *}$ & 0.00 & 0.00 \\
\hline & (1.35) & $(1.60)$ & -0.00002 & $(0.00002)$ & $(0.00)$ & $(0.00)$ \\
\hline \multirow[t]{2}{*}{ AgriPCT } & 2.93 & 4.81 & 0.00 & 0.00 & 0.00 & 0.00 \\
\hline & (7.13) & (7.98) & $(0.00)$ & $(0.00)$ & $(0.00)$ & $(0.00)$ \\
\hline \multirow[t]{2}{*}{ ServPCT } & -0.35 & -0.53 & 0.00 & 0.00 & 0.00 & 0.00 \\
\hline & (5.63) & (6.67) & $(0.00)$ & $(0.00)$ & $(0.00)$ & $(0.00)$ \\
\hline \multirow[t]{2}{*}{ Y2017 } & $685.24^{* * *}$ & -11.36 & $-0.01 * * *$ & $-0.02^{* * *}$ & $0.01^{* * *}$ & 0.00 \\
\hline & $(117.29)$ & (121.54) & $(0.00)$ & $(0.00)$ & $(0.00)$ & $(0.01)$ \\
\hline \multirow[t]{2}{*}{ GRDP } & $0.00 * * *$ & $0.00^{* * *}$ & $-0.00 *$ & $-0.00^{* * *}$ & $-0.00^{* * *}$ & 0.00 \\
\hline & $(0.00)$ & $(0.00)$ & $(0.00)$ & $(0.00)$ & $(0.00)$ & $(0.00)$ \\
\hline \multirow[t]{2}{*}{ Married } & $373.59 * * *$ & $-200.65^{* * *}$ & $-0.03^{* * *}$ & $-0.01^{* * *}$ & $0.09^{* * *}$ & $0.06^{* * *}$ \\
\hline & $(40.04)$ & (29.17) & $(0.00)$ & $(0.00)$ & $(0.00)$ & $(0.01)$ \\
\hline \multirow[t]{2}{*}{ Age } & $282.27^{* * *}$ & $215.69^{* * *}$ & $-0.00^{* * *}$ & $-0.01^{* * *}$ & $0.07^{* * *}$ & $0.08^{* * *}$ \\
\hline & (13.99) & $(12.02)$ & $(0.00)$ & $(0.00)$ & $(0.00)$ & $(0.00)$ \\
\hline \multirow[t]{2}{*}{ Agesq } & $-3.32^{* * *}$ & $-2.67^{* * *}$ & $0.00 * * *$ & $0.00 * * *$ & $-0.00^{* * *}$ & $-0.00^{* * *}$ \\
\hline & $(0.18)$ & $(0.15)$ & $(0.00)$ & $(0.00)$ & $(0.00)$ & $(0.00)$ \\
\hline \multirow[t]{2}{*}{ Constant } & $-3186.80^{* * *}$ & $-1877.73^{* * *}$ & $0.14^{* * *}$ & $0.19^{* * *}$ & $-0.51^{* * *}$ & $-0.63^{* * *}$ \\
\hline & (567.41) & (653.95) & $(0.01)$ & $(0.02)$ & $(0.05)$ & $(0.05)$ \\
\hline Province FE & Yes & Yes & Yes & Yes & Yes & Yes \\
\hline $\mathrm{N}$ & 250,606 & 223,691 & 340,343 & 325,007 & 398,146 & 415,223 \\
\hline R-sq & 0.093 & 0.082 & 0.026 & 0.03 & 0.295 & 0.235 \\
\hline
\end{tabular}

Notes: Standard errors, clustering within each province or centrally-run city, are in parentheses. ${ }^{* * *}, * *, *$ denote significance at $1 \%, 5 \%$ and $10 \%$, respectively.

Tables 6 and 7 show that the effects of SE on earnings and working hours for males and females were almost identical. However, the negative impact of SE on being unemployed was larger for females than for males: the coefficient estimates of SE are $-0.01 \%$ for females and $-0.006 \%$ for males. A similar pattern can be found for being self-employed-the negative impact of SE on being self-employed was $0.02 \%$ lower for females compared to males. In general, the results from the subsample analysis indicate that female individuals benefited more than their male counterparts from the existence of SEs, although the magnitude of the differences in the partial effects was small. 
Table 7. Regression results for working hours and being self-employed by gender.

\begin{tabular}{|c|c|c|c|c|}
\hline & (4a) & (4b) & (5a) & $(5 b)$ \\
\hline \multirow[t]{2}{*}{ Dependent Variable } & \multicolumn{2}{|c|}{ Working Hours } & \multicolumn{2}{|c|}{ Self-Employed } \\
\hline & Male & Female & Male & Female \\
\hline SE & $\begin{array}{c}0.02^{* * *} \\
(0.01)\end{array}$ & $\begin{array}{c}0.02^{* * *} \\
(0.01)\end{array}$ & $\begin{array}{c}-0.0005^{* * *} \\
(0.0002)\end{array}$ & $\begin{array}{c}-0.0007^{* * *} \\
(0.0001)\end{array}$ \\
\hline AgriPCT & $\begin{array}{l}-0.02 \\
(0.03)\end{array}$ & $\begin{array}{l}-0.03 \\
(0.04)\end{array}$ & $\begin{array}{c}0.00 \\
(0.00)\end{array}$ & $\begin{array}{c}0.00 \\
(0.00)\end{array}$ \\
\hline ServPCT & $\begin{array}{l}-0.01 \\
(0.02)\end{array}$ & $\begin{array}{l}-0.02 \\
(0.03)\end{array}$ & $\begin{array}{c}0.00 \\
(0.00)\end{array}$ & $\begin{array}{c}0.00 \\
(0.00)\end{array}$ \\
\hline Y2017 & $\begin{array}{c}-5.08^{* * *} \\
(0.57)\end{array}$ & $\begin{array}{c}-6.55^{* * *} \\
(0.70)\end{array}$ & $\begin{array}{c}-0.23^{* * *} \\
(0.02)\end{array}$ & $\begin{array}{c}-0.21^{* * *} \\
(0.01)\end{array}$ \\
\hline GRDP & $\begin{array}{l}0.00^{* *} \\
(0.00)\end{array}$ & $\begin{array}{l}0.00 * \\
(0.00)\end{array}$ & $\begin{array}{c}0.00 \\
(0.00)\end{array}$ & $\begin{array}{c}-0.00 * * * \\
(0.00)\end{array}$ \\
\hline Married & $\begin{array}{c}0.14 \\
(0.13)\end{array}$ & $\begin{array}{c}-1.32^{* * *} \\
(0.16)\end{array}$ & $\begin{array}{c}-0.02^{* * *} \\
(0.00)\end{array}$ & $\begin{array}{c}-0.02^{* * *} \\
(0.00)\end{array}$ \\
\hline Age & $\begin{array}{c}0.73^{* * *} \\
(0.04)\end{array}$ & $\begin{array}{c}0.68^{* * *} \\
(0.04)\end{array}$ & $\begin{array}{c}0.01 * * * \\
(0.00)\end{array}$ & $\begin{array}{c}0.01^{* * *} \\
(0.00)\end{array}$ \\
\hline Agesq & $\begin{array}{c}-0.01 * * * \\
(0.00)\end{array}$ & $\begin{array}{c}-0.01 * * * \\
(0.00)\end{array}$ & $\begin{array}{c}-0.00 * * * \\
(0.00)\end{array}$ & $\begin{array}{c}-0.00 * * * \\
(0.00)\end{array}$ \\
\hline Constant & $\begin{array}{c}34.18^{* * *} \\
(2.32)\end{array}$ & $\begin{array}{c}35.41^{* * *} \\
(3.00)\end{array}$ & $\begin{array}{c}0.34^{* * *} \\
(0.07)\end{array}$ & $\begin{array}{c}0.23^{* * *} \\
(0.05)\end{array}$ \\
\hline Province FE & Yes & Yes & Yes & Yes \\
\hline $\mathrm{N}$ & 333,837 & 318,424 & 333,978 & 318,524 \\
\hline R-sq & 0.093 & 0.111 & 0.135 & 0.126 \\
\hline
\end{tabular}

Notes: Standard errors, clustering within each province or centrally-run city, are in parentheses. ${ }^{* * *},{ }^{* *},{ }^{*}$ denote significance at $1 \%, 5 \%$ and $10 \%$, respectively.

\section{Discussions and Concluding Remarks}

While questions about the effect of social enterprise development on macroeconomic consequences, especially labor market outcomes, are of primary importance and can be answered only through empirical analysis in various policy contexts, previous quantitative studies that have tested empirical implications related to social enterprise development are at an early stage in this research field. We believe that this paper is the first empirical study to investigate the effect of social enterprise development on individual worker outcomes in a nationwide labor market, including labor earnings, being unemployed, labor force participation, working hours, and being self-employed. Early research regarding the impacts of SEs does demonstrate several positive effects in the labor market such as the increase of employment and working skill among the disadvantaged or the poor $[25,26]$. However, since those studies used only data of social enterprises, their results would apply to a limited set of economic sectors rather than the economy as a whole. In our study, we examined the development of SEs in Vietnam during the early 2010s, when Vietnamese provincial governments had control over policy instruments in the establishment and operation of SEs, in their broad definition. In this context, the regression model with both year and location-fixed effects can address the issue that the degree of social enterprise development (i.e., the treatment) varies among different provincial areas and across time. Hence, our empirical strategy is considered as an extension of the basic difference-indifferences methodology with multiple control and treatment groups over time. We summarize findings and provide discussion on key aspects of our empirical results below.

First, our empirical results suggest that the outcome variables regarding labor earnings and being unemployed at the individual level were improved as the number of SEs increased, indicating that a higher degree of social enterprise development contributes positively to the key aspects of labor market conditions (i.e., both price and quantity levels). The results are in line with the arguments in the social and economic literature (see Section 2) that SEs can directly reduce unemployment rates due to their utilization of 
non-market resources such as disadvantaged workers. The average earnings of all workingage individuals also slightly increased in the context of Vietnam. This may be due to the facts that social enterprise development increases the overall production efficiency and the labor market in Vietnam is relatively fragmented (e.g., urban/rural and formal/informal). Note that the effects of SEs on earnings and being unemployed for the whole economy were small in their magnitudes. This is as expected, given that the inclusion of otherwise unemployed workers and resources, accomplished by promoting SEs, only accounted for a small share of overall economic assets. Hence, the small but statistically significant benefits of increasing SEs have been supported by the empirical evidence and should not be overlooked by policymakers.

Second, we also find that social enterprise development has no effect on an individual's probability to participate in the labor force, even though we expect that augmented opportunities from all sectors (due to SEs' positive effect on production efficiency) would result in individuals returning to the labor force. A potential explanation for this result is that some working-age individuals, facing better economic conditions, chose to attend schools or training courses to build human capital. This economic force, in turn, may have canceled out the positive effect of increasing the number of SEs on labor force participation, and hence we did not observe any significant effect. For the working hours variable, the positive effect was the reinterpretation of SEs' effect on reducing unemployment or on increasing employment, given that increased working hours can be considered as higher labor supply quantity at the individual level (i.e., increment of employment). For our last outcome variable, being self-employed, the negative effect confirmed that social enterprise development indeed improves the overall economy, since the percentage of self-employed workers is much lower in developed countries than in developing ones [27].

Third, the results suggest a new policy direction in developing countries that focuses on instruments to promote social enterprise development at the local government level. This is because each local government controls certain amounts of resources or oversees the monitoring and provision of incentives to enterprises with social missions. Since they understand more about the social needs of their localities, they are in a better position to improve labor market conditions across different sectors through social enterprise policies. Moreover, for the policy goal that focuses on improving women's labor market conditions, such as employment opportunities, promoting social enterprise development within localities has shown to be successful based on our subsample analysis, and hence it should be considered as a useful instrument in the policymaker's toolbox.

Since much of the importance of social enterprise development comes from the inclusion and reintegration of disadvantaged workers, our study investigated its effect on overall labor market outcomes rather than the SE sector alone and shows its success. As the next step, it will be important to explore its effect on other development outcomes at a macroeconomic level, such as human capital accumulation or education. Additionally, the effect of social enterprise development on labor market outcomes might exhibit differences between developed and developing countries. Further research might attempt to study different aspects of social enterprise promotion within different developmental contexts.

Author Contributions: Conceptualization, N.T.T.N. and C.-T.T.; Methodology, N.T.T.N. and C.Y.W.; formal analysis, N.T.T.N. and C.Y.W.; Data curation, N.T.T.N.; Writing-original draft, N.T.T.N., C.-T.T. and C.Y.W.; Writing-review \& editing, C.-T.T., and C.Y.W. All authors have read and agreed to the published version of the manuscript.

Funding: This research received no external funding.

Institutional Review Board Statement: Not applicable.

Informed Consent Statement: Not applicable.

Data Availability Statement: Not applicable.

Conflicts of Interest: The authors declare no conflict of interest. 


\section{References}

1. OECD/ERIA. SME Policy Index: ASEAN 2018: Boosting Competitiveness and Inclusive Growth. 2018. Available online: https://www.oecd.org/investment/sme-policy-index-asean-2018-9789264305328-en.htm (accessed on 19 August 2021).

2. Borzaga, C.; Tortia, E. The economics of social enterprises. In The Economics of Social Responsibility; Borzaga, C., Becchetti, L., Eds.; Routledge: New York, NY, USA, 2010; pp. 15-33.

3. Doh, S. Social Entrepreneurship and Regional Economic Development: The Case of Social Enterprise in South Korea. Sustainability 2020, 12, 8843. [CrossRef]

4. Di Lorenzo, F.; Scarlata, M. Social Enterprises, Venture Philanthropy and the Alleviation of Income Inequality. J. Bus. Ethics 2019, 159, 307-323. [CrossRef]

5. Sarracino, F.; Fumarco, L. Assessing the Non-financial Outcomes of Social Enterprises in Luxembourg. J. Bus. Ethics 2020, 165, 425-451. [CrossRef]

6. Tortia, E. The Impact of Social Enterprises on Output, Employment, and Welfare. In The Economics of Social Responsibility; Borzaga, C., Becchetti, L., Eds.; Routledge: New York, NY, USA, 2010; pp. 55-71.

7. Defourny, J.; Nyssens, M. Conceptions of Social Enterprise and Social Entrepreneurship in Europe and the United States: Convergences and Divergences. J. Soc. Entrep. 2010, 1, 32-53. [CrossRef]

8. European Commission and OECD. Policy Brief on Scaling the Impact of Social Enterprises. 2016. Available online: https: / / www.oecd.org/cfe/leed/Policy-brief-Scaling-up-social-enterprises-EN.pdf (accessed on 26 September 2021).

9. British Council. The State of Social Enterprise in South East Asia. 2021. Available online: https://www.unescap.org/kp/2021 / state-social-enterprise-south-east-asia (accessed on 26 September 2021).

10. Becchetti, L.; Mastromatteo, G. From Economic Growth to Sustainable Development. In The Economics of Social Responsibility; Borzaga, C., Becchetti, L., Eds.; Routledge: New York, NY, USA, 2010; pp. 72-87.

11. Fields, G.S. Labor Market Analysis for Developing Countries. Labour Econ. 2011, 18, 16-22. [CrossRef]

12. CIEM. Social Enterprise in Vietnam: Concept, Context and Policies. 2012. Available online: https://www.britishcouncil.org/ sites/default/files/vietnam_report.pdf (accessed on 26 September 2021).

13. Pham, T.V. Social Enterprises in Vietnam. RECMA 2016, 342, 21-35.

14. CSIE. Fostering the Growth of the Social Impact Business Sector in Vietnam. 2018. Available online: https://www.vn.undp.org/ content/vietnam/en/home/library/SIB.html (accessed on 26 September 2021).

15. British Council. Social Enterprise in Vietnam. 2019. Available online: https://www.britishcouncil.vn/sites/default/files/socialenterprise-in-vietnam.pdf (accessed on 26 September 2021).

16. Frölich, M. Programme Evaluation with Multiple Treatments. J. Econ. Surv. 2004, 18, 181-224. [CrossRef]

17. World Bank. World Bank Open Data: Total Labor Force, Vietnam. 2020. Available online: https://data.worldbank.org/indicator/ SL.TLF.TOTL.IN?locations=VN (accessed on 26 September 2021).

18. Pasquier-Doumer, L.; Oudin, X.; Nguyen, L. The Importance of Household Business and Informal Sector for Inclusive Growth in Vietnam; Thế Giới Publishers: Hanoi, Vietnam, 2017.

19. Mincer, J. Schooling, Experience, and Earnings. Human Behavior E Social Institutions No. 2; NBER Publishing: New York, NY, USA, 1974.

20. Bargain, O.; Bhaumik, S.K.; Chakrabarty, M.; Zhao, Z. Earnings Differences between Chinese and Indian Wage Earners, 1987-2004. Rev. Income Wealth 2009, 55, 562-587. [CrossRef]

21. Wooldridge, J.M. Score Diagnostics for Linear Models Estimated by Two Stage Least Squares. In Advances in Econometrics and Quantitative Economics: Essays in Honor of Professor C. R. Rao; Maddala, G.S., Phillips, P.C.B., Srinivasan, T.N., Eds.; Blackwell: Oxford, UK, 1995; pp. 66-87.

22. Goldin, C. A Grand Gender Convergence: Its Last Chapter. Am. Econ. Rev. 2014, 104, 1091-1119. [CrossRef]

23. Blau, F.D.; Kahn, L.E. The Gender Wage Gap: Extent, Trends, and Explanations. J. Econ. Lit. 2017, 55, 789-865. [CrossRef]

24. Reskin, B.F.; Bielby, D.D. A Sociological Perspective on Gender and Career Outcomes. J. Econ. Perspect. 2005, 19, 71-86. [CrossRef]

25. Cooney, K. The Business of Job Creation: An Examination of the Social Enterprise Approach to Workforce Development. J. Poverty 2011, 15, 88-107. [CrossRef]

26. Kim, T.H.; Moon, M.J. Using Social Enterprises for Social Policy in South Korea: Do Funding and Management Affect Social and Economic Performance? Public Adm. Dev. 2017, 37, 15-27. [CrossRef]

27. Fields, G.S. Self-employment and Poverty in Developing Countries. IZA World Labor 2019, 1-60. [CrossRef] 